\title{
ALK Rearrangement Testing Method
}

National Cancer Institute

\section{Source}

National Cancer Institute. ALK Rearrangement Testing Method. NCI Thesaurus. Code C158850.

A request to enter the specific molecular analysis method used to detect and identify rearrangements involving the ALK gene. 